\title{
Finding Information on the Internet
}

\author{
Lect.dr. Gabriela GROSSECK \\ Universitatea de Vest din Timişoara
}

The main problem on the Internet is not having access to information, but the way in which the information is filtered and selected appropriately. Because the Internet is a huge reservoir of information which does not benefit from the services of a librarian or a catalogue, the search engines have an increasingly important role in selecting the information. Statistics show that over $80 \%$ of the traffic to Internet sites is generated by search engines. If 8 out of 10 Internet users turn to a search engine in order to find the desired information, about the same number of people say they are frustrated by the inability of getting this information. Hence, the increasing importance of selecting information by the search engines, as well as filtering the information content by the user. These are the issues dealt with in this article.

Keywords: Internet, information, search engine, Internet users.

$\mathbf{P}$ roblema principală în Internet nu o mai reprezintă accesul la informație ci modul în care aceasta este filtrată şi selectată în mod optim. Deoarece Internetul este un vast rezervor de informație care nu beneficiază de un bibliotecar sau catalog, o importanță crescândă în selectarea informațiilor o au serviciile de căutare. Statisticile arată că peste $80 \%$ din totalul de trafic către site-uri în Internet este generat de motoarele de căutare. Dacă 8 din 10 internauți apelează la un serviciu de căutare pentru a găsi informațiile dorite cam tot atâția se declară frustrați de inabilitatea de a le obține. De aici importanța crescândă în selectarea informațiilor atât a serviciilor de căutare cât şi a filtrării conţinutului informațional de către utilizator, subiecte tratate în prezentul articol.

Informații s-au obținut cu mult timp înainte de a apărea Internetul: cataloagele de felicitări electronice, sistemele de rezervare a biletelor de călătorie etc. aveau încorporate facilități de căutare. Istoria ${ }^{1}$ acestor tipuri de servicii a început în 1990 odată cu primele motoare de căutare pe Internet. Aşa au apărut Archie, Veronica, Jughead şi Gopher, denumite după personaje din cărți de benzi desenate datorită ciudatului simț al umorului avut de tehnicienii timpului. Câțiva ani mai târziu

1 Părintele tehnologiei de căutare este profesorul George Salton (1927-1995), ale cărui contribuţii se găsesc în cartea „A Theory of Indexing”. şi-au făcut intrarea Yahoo! (1994) şi Google (1997).

Cele mai populare mijloace de găsire a informațiilor sunt motoarele de căutare, peste $80 \%$ dintre utilizatorii de Internet apelând la aceste aplicaţii de localizare a datelor. Există însă şi alte surse de informare disponibile pe Web precum directoarele specializate, forumurile de discuții, site-urile de tip wiki, portalurile web, weblogurile sau rețelele sociale (Flickr sau del.icio.us). $\mathrm{Cu}$ ajutorul acestora practic putem găsi orice informație dorim: ştiri despre conflictele din Irak, informații despre testarea națională a elevilor, imagini de pe Marte, videoclipurile melodiilor din cadrul festivalului EuroVision, harta județului Arad, fotografii ale Cascadei Niagara, prezentări în PowerPoint de la diverse conferințe academice etc.

Conform statisticilor (figura 1) piața motoarelor de căutare este dominată de giganții media Google, Yahoo! şi Microsoft.

Chiar dacă a căuta ceva pe Internet astăzi pare a fi un lucru banal acest proces seamănă mai mult cu a draga suprafața unui ocean cu o plasă de pescuit. Astfel cu toate că în ea se prind peşti există riscul ca cei doriți să nu se afle în plasă. În mod similar, informația ,aflată” la suprafața Internetului este doar o mică parte din „oceanul de cunoaştere” virtual. Adesea motoarele de căutare nu găsesc ceea ce noi căutăm, cu toate că se bazează pe 
indexarea paginilor cu ajutorul roboților sau agenților de căutare. Pentru a fi descoperită o pagină trebuie să fie statică şi legată de alte pagini. Dar cum Webul este dinamic există toate şansele ca informația căutată să nu fie găsită în urma unei căutări standard.

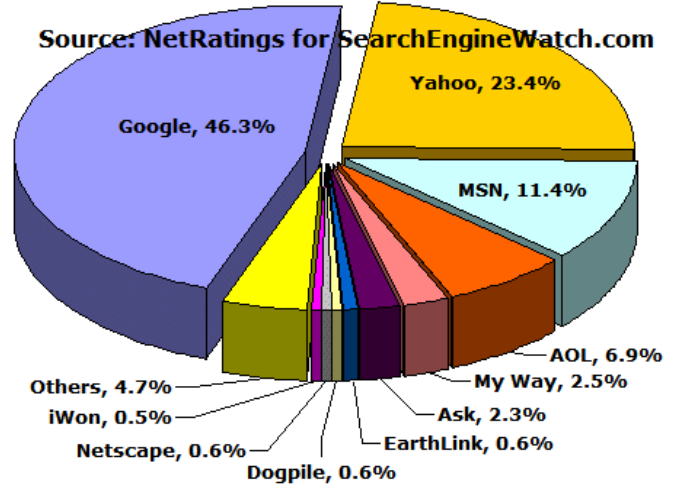

sursa: SearchEngineWatch.com, aprilie 2006

Fig.1. Piața motoarelor de căutare

Teoretic Web-ul are două părți mari: Web-ul de suprafață şi Web-ul de adâncime (profund).

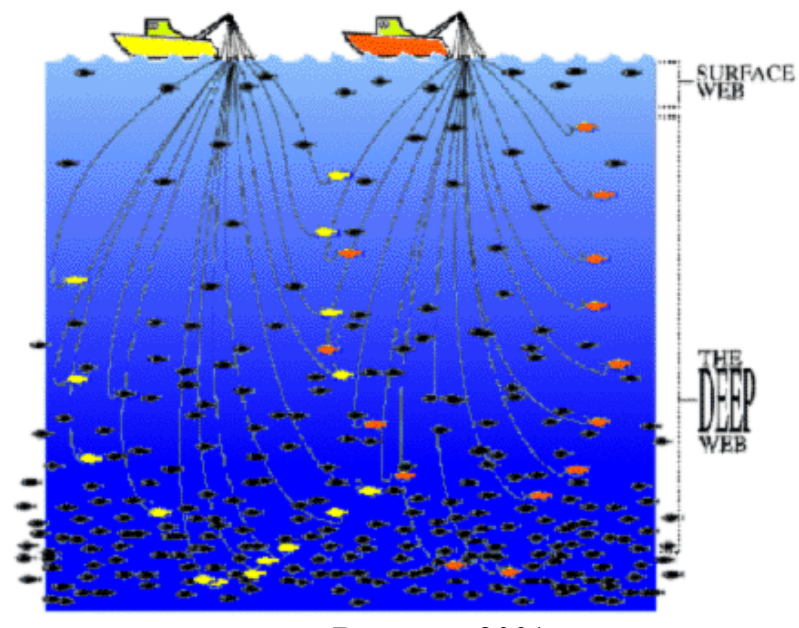

sursa: Bergman, 2001

Fig.2. Simbolizarea grafică a limitărilor unei căutări tipice cu ajutorul motoarelor de căutare

Într-un studiu recent realizat de BrightPlanet, o companie specializată în tehnologii de căutare, se arată că Web-ul profund este de până la 500 de ori mai mare decât ceea ce noi cunoaştem azi ca WWW. Deoarece doar 16\% dintre site-uri sunt catalogate de motoarele de căutare $^{2}$ uneori mai este referit ca „Web-ul

2 Lawrence, S.; Giles, C.L., Accessibility of information on the Web, Nature 400: 107, 1999. invizibil". În medie, site-urile conținute în Web-ul profund generează cu peste $50 \%$ mai mult trafic decât cele de la suprafață. Şi, ceea ce este mai important, calitatea informației este de cca. 2000 de ori mai mare. $\mathrm{Cu}$ alte cuvinte, World Wide Web-ul este doar un subset de informații al conținutului disponibil on-line. În general, utilizatorii îşi localizează informația dorită pe Internet fie prin navigare directă (cunoaşterea adresei), fie ca răspuns la o „recomandare” (includerea adresei de site în semnătura unui email, urmărirea unui banner, consultarea unui blog, legătură de la o altă pagină web etc.), în urma unei cereri de interogare într-un motor de căutare, vizite repetate sau datorită activităților clasice de marketing şi comunicare. Dintre aceste modalități, căutarea pe cuvinte cheie relevante, în special pe construcții formulate în limbaj natural (Buraga, 2005), este cea mai bună cale de obținere a informațiilor dorite.

De aceea, de o importanţă foarte mare este considerată anticiparea modalităților de căutare la care apelează utilizatorii pentru a ajunge cât mai uşor la un site. Pentru aceasta trebuie să înțelegem în primul rând cum are loc căutarea. Astfel, cu toate că marea majoritate suntem tentaţi să privim procesul de căutare ca fiind linear (figura 3a) în realitate, modelul clasic al unei căutări este complet diferit (figura 3b). O căutare tipică se dovedeşte a fi, de cele mai multe ori, un proces complex şi circular, cu multiple interacțiuni cu site-urile şi lista de rezultate. În general o căutare standard implică 5-6 interogări diferite şi 15-20 interacțiuni cu site-uri diferite. Uneori, interogarea conduce utilizatorul întro direcție opusă, furnizând un rezultat cu totul divergent față de scopul căutării iniţiale. Înfundăturile şi butonul ,back” sunt des întâlnite în cadrul unui proces de căutare. Din aceste motive, lista de rezultate a motorului de căutare este privită mai mult ca un instrument ajutător de navigare.

În funcție de utilizator, s-a constatat că pagina de rezultate a unui motor de căutare este împărțită pe secțiuni, care fie sunt studiate fie sunt ignorate, situație caracteristică în special pentru listele sponsorizate Google: aproape $80 \%$ dintre utilizatori merg direct la lista or- 
ganică. $\mathrm{Cu}$ toate acestea, un procent semnificativ de utilizatori nu fac diferența între legăturile sponsorizate şi cele din lista organică de rezultate, cu excepția utilizatorilor MSN
(71,2\% conform iProspect), care apreciază astfel de rezultate ca fiind relevante sau foarte relevante cererilor de interogare lansate.

a)

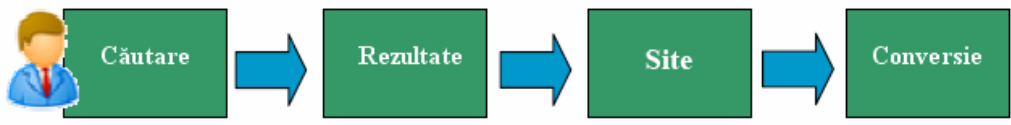

a)

b)

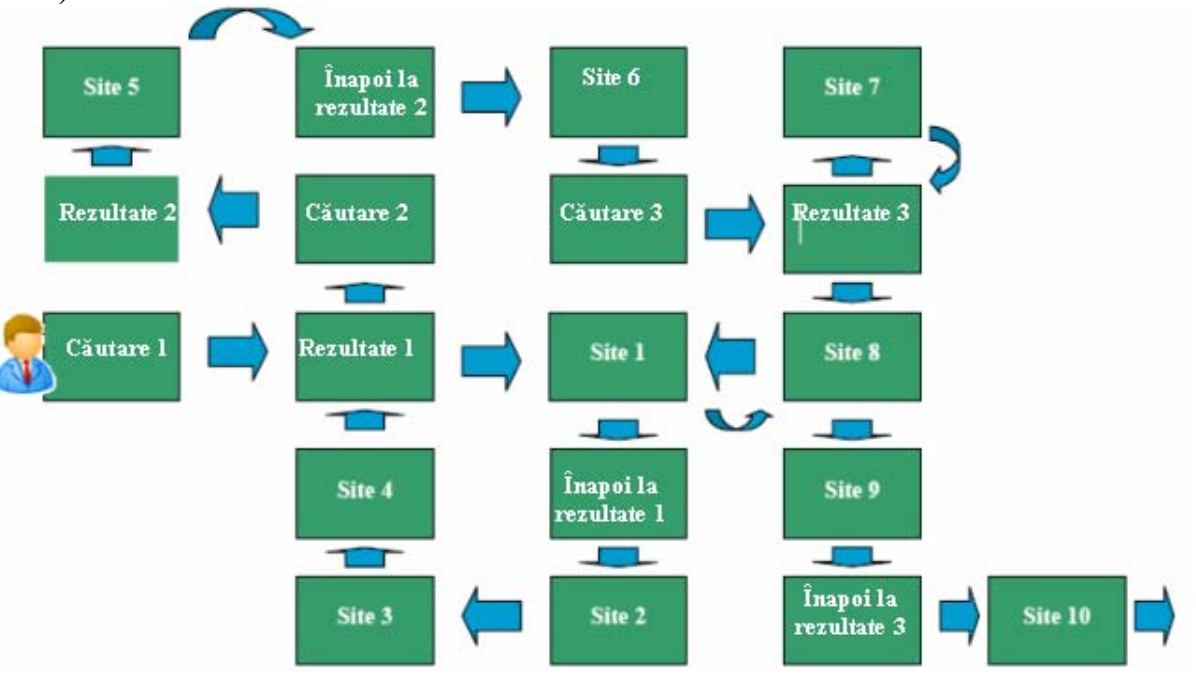

Fig.3. Procesul de căutare
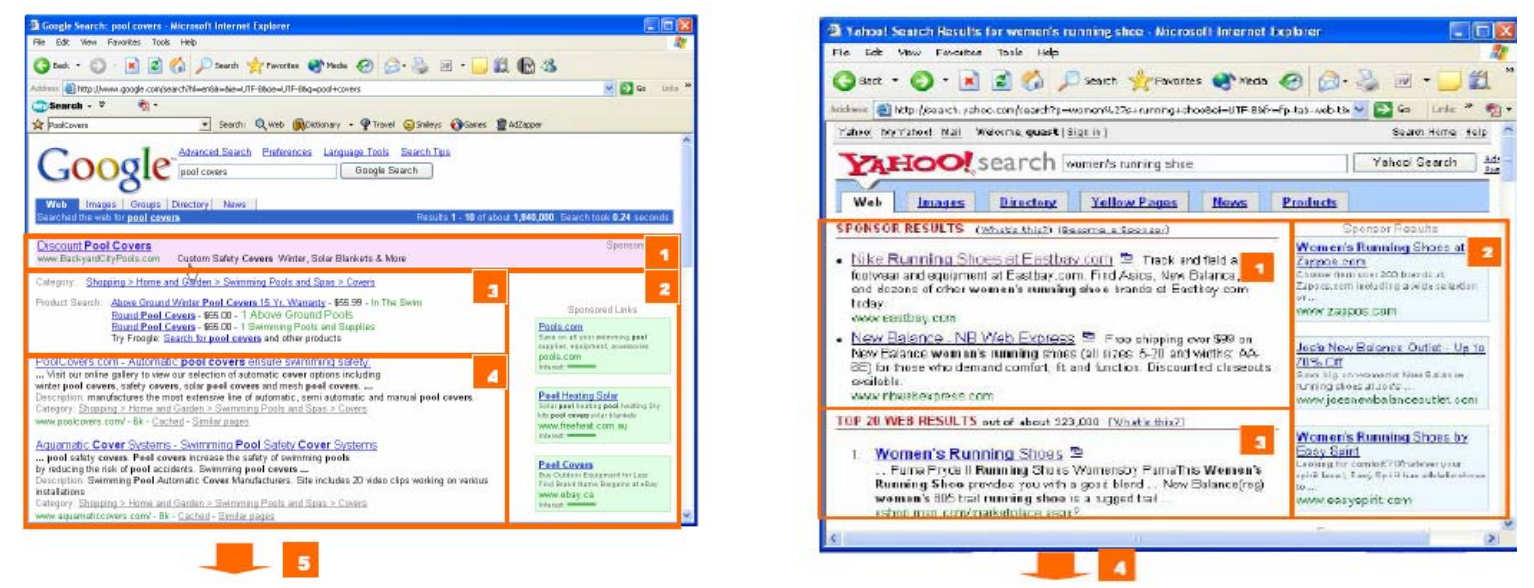

Fig.4. Secțiunile motoarelor de căutare Google şi Yahoo!

\section{5 secțiuni pe Google}

1. Legături sponsorizate în partea de sus a listei (nu apar de fiecare dată).

2. Legături sponsorizate în partea laterală.

3. Informații opționale (ex. Ştiri sau Froogle) care apar deasupra listei organice de rezultate.

4. Lista organică de rezultate pe care utilizatorul o vede (depinde de monitor).

5. Restul rezultatelor din listă pentru care utilizatorul foloseşte bara de derulare verticală ca să le vadă.

Elementele care atrag atenția utilizatorilor sunt cuvintele cheie din titlu şi descrierea rezultatelor. După ce au identificat legătura ca-

\section{4 sectiuni pe Yahoo!}

1. Legături sponsorizate în partea de sus a listei.

2. Legături sponsorizate în partea laterală.

3. Lista organică de rezultate pe care utilizatorul o vede (depinde de monitor).

4. Restul rezultatelor din listă pentru care utilizatorul foloseşte bara de derulare verticală ca să le vadă

re corespunde cererii lor de căutare utilizatorii dau clic pentru a accesa pagina.

Fiecare motor de căutare are propriul set de 
reguli şi proceduri asupra modului de indexare a paginilor Web, denumit algoritm. Din cauza diferențelor dintre algoritmi (titlul paginii, primul paragraf, primele 250 de cuvinte, numărul de legături etc.) este posibil ca aceleaşi cuvinte cheie să genereze rezultate diferite în motoare de căutare diferite. Spre exemplu, puțin peste $50 \%$ dintre rezultatele motoarelor de căutare Google şi Yahoo! se potrivesc.

Capacitatea motoarelor de căutare de a afişa informații relevante depinde şi de relațiile dezvoltate între acestea: dacă îşi foloseşte propria bază de date, a altor motoare sau oferă informații şi pentru alte motoare de căutare. Ierarhia rezultatelor ,scotocitorilor digitali" poate fi urmărită pe patru niveluri:

1. Rezultate oferite de către furnizori prin- cipali de informație. Motoarele de căutare se bazează în primul rând pe rezultatele proprii. Google, de exemplu, şi-a dezvoltat propriul algoritm: o căutare cu acest motor nu depinde de alte servicii de căutare.

2. Rezultate oferite de către furnizori secundari de informație. Dacă primul provider eşuează în a căuta informații relevante, atunci motoarele apelează la furnizori secundari de informație. Este un fel de opțiune de backup. 3. Rezultate extrase din directori de căutare. Motoarele de căutare se folosesc şi de rezultatele din directoare.

4. Rezultate plătite (legăturile sponsorizate): clienții plătesc pentru a se afla în topul căutărilor pentru anumite cuvinte cheie.
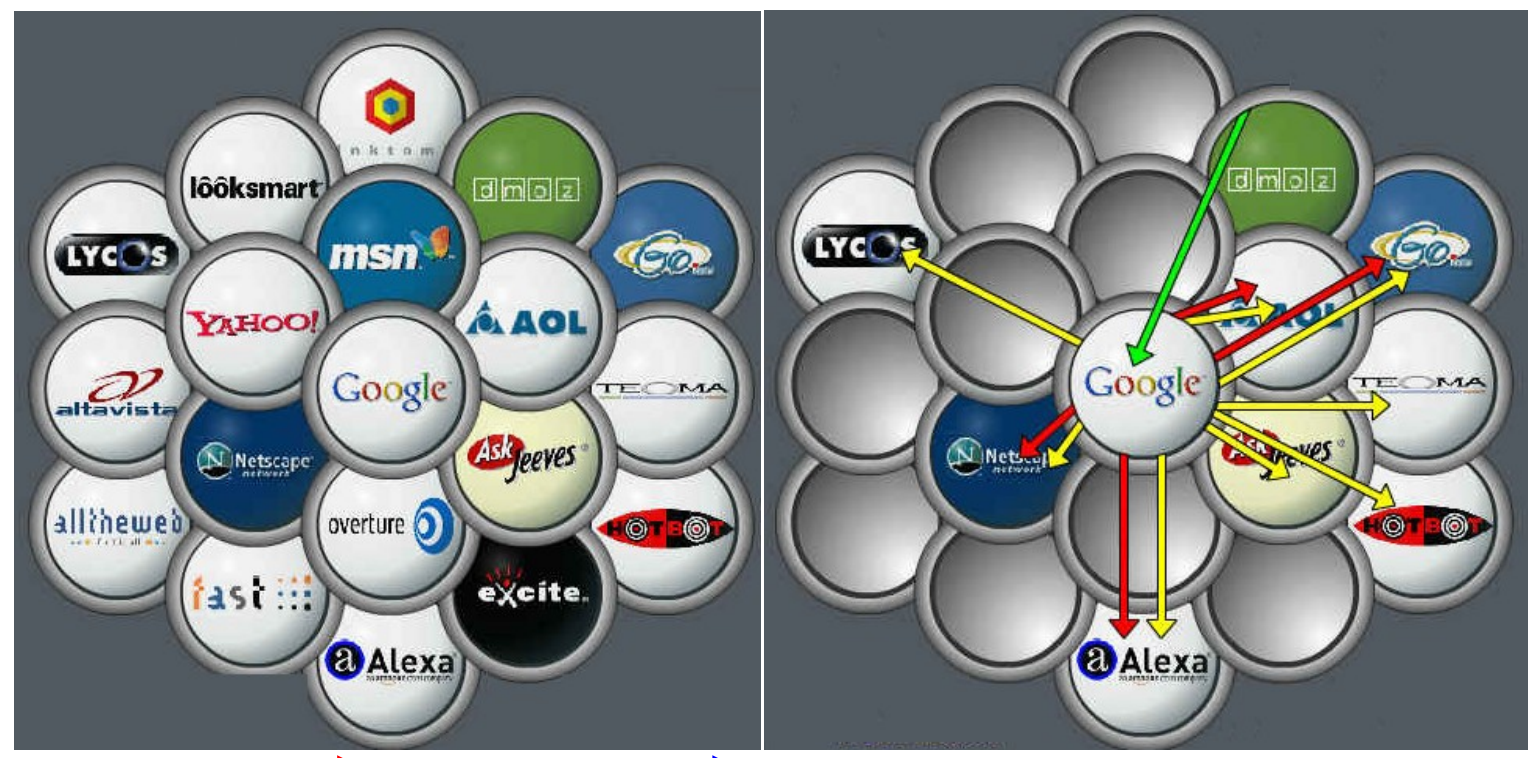

Legendă:

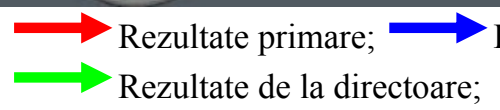

Rezultate secundare

Rezultate plătite

Fig.5. Harta relațiilor dintre diverse motoare de căutare (www.bruceclay.com)

Odată ajunşi pe site utilizatorii trebuie să poată accesa rapid informațiile de care au nevoie. Există o regulă denumită ,regula celor 3 clic-uri", care spune că utilizatorul din maximum trei apăsări ale butonului stâng al mouse-ului trebuie să poată accesa informațiile care să influențeze acțiunile sale. În plus, experiența utilizatorului de Internet, timpul petrecut on-line, frecvența utilizării, domeniile de interes, preferința pentru un anumit motor de căutare, motivaţia alegerii unui motor de căutare, vârsta, educația, venitul etc. sunt factori pe care cei interesați/implicați în procesul de optimizare a site-urilor nu au voie să îi ignore. Răspunsuri la întrebări cum ar fi:

- Câți utilizatori de Internet vizitează motoarele de căutare?

- Care este demografia utilizatorilor serviciilor de căutare?

- Ce îi determină pe utilizatori să caute online?

- Cât de des folosesc utilizatorii motoarele de căutare?

- Ce motoare de căutare preferă utilizatorii? 
- Cât de importantă este încrederea în rezultatele oferite?

- Cum îşi construiesc utilizatorii cererile de interogare?

- Cât de relevantă este o căutare? Ce fac utilizatorii dacă nu obțin informațiile dorite?

- Sunt marea majoritate a utilizatorilor conştienți de legăturile sponsorizate?

- Ce îi determină pe utilizatori să facă clic pe rezultate?

- Ce preferă utilizatorii: reclame plătite în procesul de căutare sau listele organice, clasice de rezultate? ş.a.m.d.

sunt esenţiale, pentru că oferă o mai bună înțelegere a modelelor de căutare şi interacțiunile cu site-ul.

În general, utilizatorii de Internet sunt mulțumiți de experiența căutărilor on-line. Conform unui studiu realizat de US Pew Research Center în 2004, 44\% dintre utilizatori folosesc doar un singur motor de căutare, iar $48 \%$ două sau trei. Aproape jumătate dintre ei utilizează un motor de căutare de câteva ori pe săptămână, însă $2 / 3$ afirmă că ar putea trăi fără a simți lipsi vreunui serviciu de căutare a informațiilor. Deşi internauții au încredere în motorul de căutare preferat, ei nu înţeleg modul de operare şi de prezentare a rezultatelor acestor motoare: doar 38\% dintre aceştia ştiu diferența dintre rezultatele cu taxă şi cele gratuite şi doar una din şase persoane poate defini cu exactitate care rezultate sunt plătite şi care nu.

Este interesant de urmărit şi cine pe cine vizitează cu predilecție. De exemplu, americanii preferă site-urile australiene, braziliene, cehe şi daneze, în timp ce englezii preferă siteurile latine (franceze, spaniole şi italiene). Preferințele germanilor se îndreaptă spre siteuri italiene, spaniole, ruse şi englezeşti iar cele ale francezilor către site-urile vecinilor spanioli şi germani.

În mediul on-line toate activitățile de promovare care implică motoarele de căutare intră în categoria marketingului motoarelor de căutare (Search Engine Marketing, SEM pe scurt). Promovarea unei organizații/produs/brand cu motoarele de căutare este importantă în primul rând pentru că este o metodă neintruzivă de marketing on-line: nu în- trerupe în nici un fel activitatea navigatorului (vizitatorul primeşte ceea ce caută, în momentul în care caută). În al doilea rând, este o metodă bazată în întregime pe voluntariatul utilizatorului de Internet. Acesta decide ce legătură urmează. În al treilea rând, permite o identificare a organizației/produsului/brandului cât mai uşoară, oferind posibilitatea de a cere detalii. Şi, nu în ultimul rând, SEM-ul este folosit atât pentru atragerea de noi clienţi, cât şi pentru păstrarea celor existenți, deoarece un site de succes, care să atragă cât mai mulți vizitatori şi să-i determine să revină, presupune furnizarea de informații utile şi de calitate, actualizare permanentă a contținutului, navigare uşoară, încărcare şi feedback rapid.

Marketingul motoarelor de căutare cuprinde o serie de tehnici, dintre care cele mai importante sunt:

a) Search Engine Submissions (SES - Inscrierea în motoarele de căutare) - cuprinde serviciile necesare înscrierii web site-ului în toate motoarele de căutare majore.

b) Search Engine Optimization (SEO Optimizarea pentru motoarele de căutare) se referă la poziționarea de top în motoarele de căutare. SEO este doar o parte a strategiei de promovare pe Internet, însă este cea mai importantă.

c) Site Linking and Link Popularity (SLLP - Legarea către alte web site-uri şi popularitatea web site-ului pe motoarele de căutare şi pe Internet) - strategiile pentru legături aduc mai mult trafic şi ridică clasificarea în motoarele de căutare.

\section{d) Search Engine Ranking Reports} (SERR - Raportarea clasării în motoarele de căutare) - cum este clasificat şi ce poziție ocupă website-ul în motoarele de căutare.

În ceea ce priveşte implicarea în sectorul de business, studii recente au constatat că utilizarea motoarelor de căutare este pilonul pe care se sprijină luarea unei decizii de cumpărare, atât la nivel de afacere cât şi la nivel de utilizator. Conform iProspect pe primul loc pentru găsirea informației se situează motorul de căutare Google $(65,8 \%)$, existând diferențe însă în funcție de venit, educaţie şi sex. Pe al doilea se găseşte Yahoo! (55,2\%), urmat la 
mică diferență de MSN (53,7\%) şi AOL cu 48, $6 \%$.

Apropiate de datele furnizate de iProspect sunt şi cele din studiul Enquiro în care se arată că Google reprezintă prima alegere pentru $72,4 \%$ din utilizatorii cu venituri mici şi pentru $86,9 \%$ din utilizatorii cu venituri mari. Alegerea Google ca şi primă sursă de informații este mai mare şi în rândul celor cu studii universitare şi postuniversitare $(86,6 \%)$, spre deosebire de $67,8 \%$ dintre cei cu studii liceale. În ceea ce priveşte sexul, mai mulți bărbați, $86,7 \%$ decât femei $(80 \%)$ preferă Google ca primă destinație pentru căutarea de informații. Şi tot bărbații petrec mai mult timp scotocind în listele de rezultate; conform iProspect, 44\% dintre femei declară că nu consultă a două pagină de rezultate. Acelaşi studiu mai arată că cu cât utilizatorii sunt mai înaintați în vârstă cu atât sunt mai dispuşi să petreacă mai mult timp studiind rezultatele motoarelor de căutare. Timpul petrecut on-line pentru a căuta informația este, în medie, de circa 4 ore/zi şi se consumă în majoritate la servici.

Dintre utilizatorii de business intervievați de Marketing Sherpa 93,2\% au indicat faptul că informațiile despre produsul/serviciul care poate constitui obiectul unei tranzacții sunt căutate în primul rând on-line. Numai 4,46\% au răspuns că nu vor folosi motoarele de căutare ca şi metodă de găsire a informațiilor dorite.

Tabelul 1 - Destinații pentru culegerea informațiilor de către utilizatorii business

\begin{tabular}{|l|l|}
\hline & Procent \\
\hline Motoare de căutare & 63,9 \\
\hline $\begin{array}{l}\text { Site-urile producătorilor cunos- } \\
\text { cuți }\end{array}$ & 18,9 \\
\hline $\begin{array}{l}\text { Portaluri specifice domeniului de } \\
\text { interes }\end{array}$ & 6,6 \\
\hline $\begin{array}{l}\text { Site-uri cu conținut neutru despre } \\
\text { produsul/serviciul căutat }\end{array}$ & 5,3 \\
\hline Site-uri de comerț electronic & 3,1 \\
\hline Altele & 2,2 \\
\hline
\end{tabular}

Interesantă este legătura dintre aceste destinaţii de cercetare on-line şi bugetul alocat viitoarei tranzacții. Astfel, cu cât bugetul este mai mare, cu atât şansele ca destinațiile de cercetare on-line, altele decât motoarele de căutare, să devină prima sursă de informații, cresc. Însă, indiferent de mărimea bugetului, motoarele de căutare rămân întotdeauna prima sursă de informații pentru majoritatea utilizatorilor business $(53,5 \%$ pentru bugete cuprinse între $10.000 \$-50.000 \$)$, în timp ce la acelaşi buget, site-urile producătorilor cunoscuți reprezintă prima sursă de informații pentru $25,4 \%$ din utilizatori. Pentru bugetele sub 500 \$ şi până în $1000 \$$, motoarele de căutare domină cu $72,1 \%$, respectiv $67,2 \%$ din preferințele pentru prima destinație de căutare online.

Intensitatea utilizării motoarelor de căutare scade pe măsură ce utilizatorul se apropie de finalizarea tranzacției. Din figura nr. 6 se observă că, din cei $68 \%$ de utilizatori care folosesc motoarele de căutare pentru a obține informații înainte de a cumpăra un produs, doar $28 \%$ ajung să cumpere efectiv on-line.

Specialiştii de la Enquiro.com au identificat patru tipuri de utilizatori care folosesc motoarele de căutare şi care se diferențiază prin: tipul de secțiune scanată a listelor de rezultate, tipul de site-uri accesate; timpul de decizie asupra relevanței unui site accesat şi probabilitatea de conversie din căutător în client. Comportamentele distincte ale fiecărui grup pot avea un impact dramatic asupra succesului unei campanii de marketing prin motoarele de căutare. Mai mult, aceste modele de căutare afectează tipul de site-uri pe care se dă clic, partea vizualizată din rezultatele căutării, timpul necesar deciziei de a face clic pe un site şi, nu în ultimul rând, rata de conversie a prospectului odată ce a vizitat site-ul. Cele patru tipuri de utilizatori ai motoarelor de căutare sunt:

a) Repezitul (The scan and clicker). Citeşte foarte rapid primele 3-4 titluri ale primei pagini de rezultate. Deoarece presupune că rezultatele din top sunt cele mai relevante, are tendința de a le accesa fără a citi cu atenție descrierile afişate, decizia asupra relevanței site-ului accesat fiind luată destul de rapid, în 10-15 secunde. În general nu are răbdarea necesară de a vizualiza şi a doua pagină de rezultate.

b) Cumpătatul (The 2 step scanner). Citeşte primele 3-4 titluri ale primei pagini de re- 
zultate şi accesează numai acele titluri care ies în evidență. Dacă nici un rezultat din acestea nu-i trezeşte interesul, va coborî mai jos în prima pagină de rezultate, citind mai în detaliu titlurile şi descrierile. Rareori accesează cea de a treia pagină de rezultate. Înainte de a deveni client accesează şi cercetează mai multe site-uri.

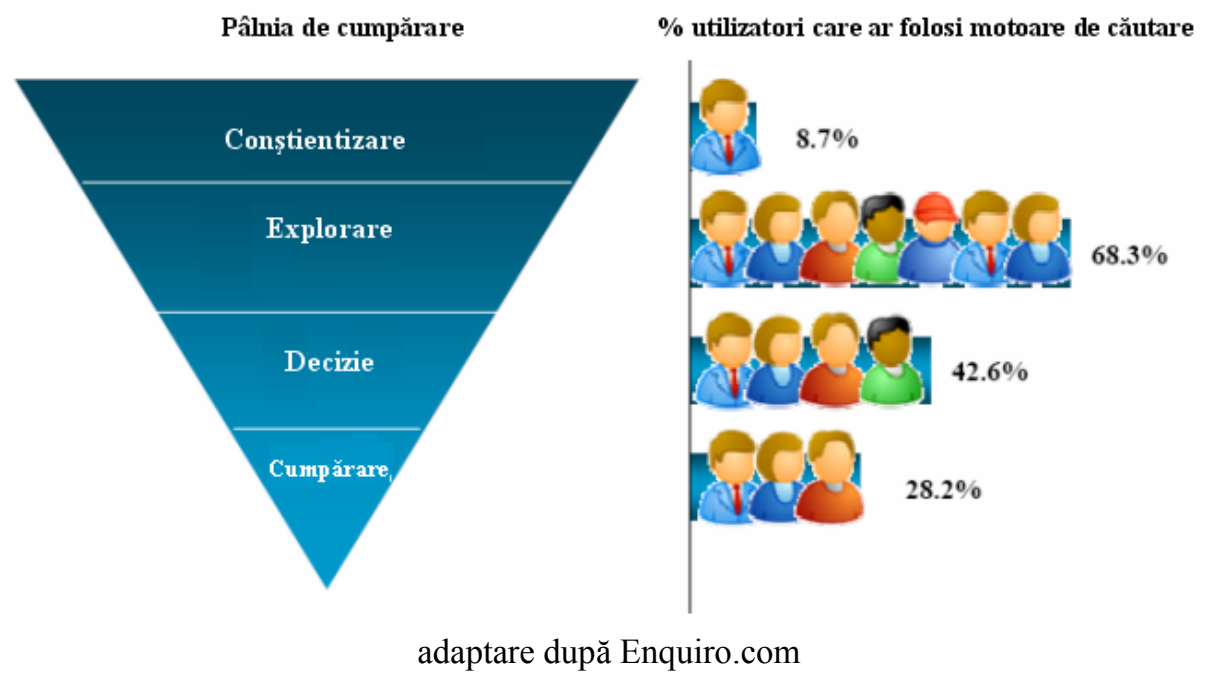

Fig.6. Comportamentul consumatorilor în luarea deciziei de cumpărare

Specialiştii de la Enquiro.com au identificat patru tipuri de utilizatori care folosesc motoarele de căutare şi care se diferenţiază prin: tipul de secțiune scanată a listelor de rezultate, tipul de site-uri accesate; timpul de decizie asupra relevanței unui site accesat şi probabilitatea de conversie din căutător în client. Comportamentele distincte ale fiecărui grup pot avea un impact dramatic asupra succesului unei campanii de marketing prin motoarele de căutare. Mai mult, aceste modele de căutare afectează tipul de site-uri pe care se dă clic, partea vizualizată din rezultatele căutării, timpul necesar deciziei de a face clic pe un site şi, nu în ultimul rând, rata de conversie a prospectului odată ce a vizitat site-ul. Cele patru tipuri de utilizatori ai motoarelor de căutare sunt:

c) Repezitul (The scan and clicker). Citeşte foarte rapid primele 3-4 titluri ale primei pagini de rezultate. Deoarece presupune că rezultatele din top sunt cele mai relevante, are tendința de a le accesa fără a citi cu atenție descrierile afişate, decizia asupra relevanței site-ului accesat fiind luată destul de rapid, în 10-15 secunde. În general nu are răbdarea necesară de a vizualiza şi a doua pagină de rezultate.

d) Cumpătatul (The 2 step scanner). Citeşte primele 3-4 titluri ale primei pagini de re- zultate şi accesează numai acele titluri care ies în evidență. Dacă nici un rezultat din acestea nu-i trezeşte interesul, va coborî mai jos în prima pagină de rezultate, citind mai în detaliu titlurile şi descrierile. Rareori accesează cea de a treia pagină de rezultate. Înainte de a deveni client accesează şi cercetează mai multe site-uri.

e) Precautul (The deliberate researcher). Citeşte toate rezultatele din prima pagină cu foarte mare atenție înainte de a selecta ceva, fiind posibilă chiar verificarea credibilității adreselor web (40\% din acest tip de utilizatori vizualizează şi a doua pagină de rezultate).

f) Minuțiosul (The 123 searcher). Citeşte titlurile şi descrierile rezultatelor în ordinea în care apar, accesând fiecare site care îi va stârni interesul, fără a lua în considerare următorul rezultat, decât numai după ce termină de răsfoit adresa accesată; dacă aceasta nu corespunde aşteptărilor va folosi butonul back pentru întoarcerea în lista de rezultate. O problemă deloc de neglijat o constituie faptul că utilizarea serviciilor de căutare are şi unele consecințe negative precum:

- lipsa unei hărți globale de navigare (Buraga, 2005) poate determina o navigare complet nestructurată;

- viteza mică de oferire a rezultatelor poate 
conduce la abuzuri asupra timpului şi răbdării utilizatorilor;

- distilarea defectuoasă a rezultatelor poate conduce la informații duplicat sau nerelevante;

- în cazul dispozitivelor mobile utilizatorii se pot confrunta cu anumite constrângeri tehnologice datorate dimensiunii reduse ale ecranelor, lățimii de bandă şi a costurilor de conectare ridicate.

În loc de încheiere câteva considerații de natură etică:

- Influențarea cunoaşterii. Căutarea este importantă mai ales pentru că modul prin găsim rezultatele afectează, prin extensie, cum învățăm şi ce ştim. De altfel, apelarea la serviciile de căutare pe Internet a redus aproape la minim rolul bibliotecarilor.

- Oferirea de rezultate false slăbeşte încrederea tehnologică.

- Incălcarea drepturilor de copyright. Dorința companiei Google de a oferi utilizatorilor de Internet cea mai mare bibliotecă din lume prin serviciul Google Print a stârnit vii proteste din partea caselor de editură.

- Supravegherea căutărilor prin monitorizarea comportamentului de navigare (cookies, cache-ul de la Google, reclamele din Gmail etc.).

- Utilizarea ca instrument de hacking. Spre exemplu cu ajutorul motorului de căutare Google se poate afla aproape orice: de la nume de utilizatori, parole, numere de cărți de credit la informații foarte personale.

- Incălcarea intimității utilizatorilor prin furnizarea unor informații autorităților pentru a fi folosite ca probe în procese împotriva lor. În țări în care domneşte cenzura precum China, Vietnam, Cuba sau Iran acestea pot duce la condamnarea internautilor.

- Blocarea accesului la unele site-uri la solicitările autorităţilor (Yahoo şi Google la cererea autoritătilor chineze s-au autocenzurat pentru anumite site-uri pe probleme sensibile ca, de exemplu, situaţia Tibetului, independența Taiwanului sau protestele antiguvernamentale din piața Tiananmen din 1989).

\section{Bibliografie}

1.Bergman, Michael K., „The Deep Web: Surfacing Hidden Value", The Journal of Electronic Publishing, august, 2001, 7(1), www.press.umich.edu/jep/07-

01/bergman.html.

2.Buraga, Sabin, Proiectarea siturilor web, ediţia a II-a, Editura Polirom, Iaşi, 2005.

3.Fallows, Deborah; Rainie, Lee, The Popularity and Importance of Search Engines, Pew Internet\&American Life Project, 2004.

4.Foster, Peter, The perils of the keyword search, http://www.telegraph.co.uk, 16 iunie 2006.

5.Hotchkiss, Gord (coord.), Into the Mind of The Searcher, Enquiro Search Solutions, www.enquiro.com, 2004.

6.Hotchkiss, Gord; Jensen, Steven; Jasra, Manoj; Wilson, Doug, The Role of Search in B2B Buying Decisions, Enquire\&MarketingSherpa, octombrie 2004, http://www.marketingsherpa.com/b2b-

bd/B2BSurveySummary.pdf.

7.iProspect, WebSurveyor, Stratagem Research, Survey Sampling International LLC, iProspect Search Engine User Attitudes, aprilie-mai 2004, www.iprospect.com. 